\title{
THE SANITARY SIGNIFICANCE OF COLIFORM BACILLI IN SOIL
}

\author{
By J. S. RANDALL \\ Public Health Laboratory, Cardiff
}

Considerable conflict exists as to whether coliform bacilli may be found in the absence of faecal pollution. The opinion expressed in the Ministry of Health Report No. 71 in 1939 was that Bacterium coli type I and irregular I are of intestinal origin, but that the primary habitat of the other coliform types, the citrate users, probably lay in soil and on vegetation. Parr (1939), however, held the opinion that 'all of the coliform bacteria must be thought of as possibly faecal in origin'. This opinion was unsupported by Griffin \& Stuart (1940), who found the distribution of 6577 strains of coliforms in milk, water, soil, grains and faeces to suggest that Aerobacter (aerogenes) group and intermediates constituted the normal coliform flora of non-faecal materials while Escherichia (Bact. coli type I) were normal to faeces. Taylor (1942), however, studied the results of previous workers on the ecology of the coliform bacteria and found insufficient evidence to conclude that aerogenes and intermediate types were normal inhabitants of the soil, grasses and grains. Bardsley (1948) reported that when soil plots were watered with suspensions of Bact. coli type I, intermediate type I and Bact. aerogenes type I, all three types tended to die out gradually and that there was no question of the aerogenes or intermediate types growing and multiplying. In 1949, Thresh, Beale \& Suckling joined with such authorities as the Ministry of Health (1939) and Topley \& Wilson (1946) in stating that the probable habitat of Bact. coli type II, the intermediate and the aerogenes types, lay outside the intestine in soil and vegetation. Taylor (1951), in an examination of soils collected from widely separated locations in the United Kingdom and in Denmark, found the most prevalent coliform organism isolated to be Bact. coli type I. Of 75 soils examined only 43 showed any coliform bacteria present in $15 \mathrm{~g}$.; of these $63 \%$ had less than 10 coliform organisms per gram and only $11 \%$ had more than 100 coliforms per gram. Taylor considered the evidence supported the view that soil was not the natural habitat of either the intermediate types or Bact. coli type II. He thought it likely that the most important habitat of all major coli-aerogenes types was in faeces.

Using a primary isolation temperature of $30^{\circ} \mathrm{C}$., Thomas, Jones \& Franklin (1951) found aerogenes-cloacae type to predominate in soil-polluted waters. In 1952, Thomas \& McQuillin, also using a primary isolation temperature of $30^{\circ} \mathrm{C}$., found all types of coliforms in grass samples taken from both grazed and ungrazed herbage. Aerogenes-cloacae types were in the majority, and intermediate types were well represented.

In the work reported here samples of soil were examined in order to enumerate and identify the coliforms present. It was thought that bacteria living in their natural habitat would exist in large numbers, and quantitative analyses were thus 
considered essential in the survey. The usual method used by previous workers in surveys of this kind was to inoculate a fluid medium which, after incubation, was plated out on MacConkey's medium to isolate the coliforms. When the tests were done quantitatively several tubes of fluid media were inoculated with varying amounts of the sample. Preliminary trials with this technique showed that there could be great errors. It appeared a valid enough technique when a very highly selective solid culture medium could be used to separate the various species present in the broth, as, for example, in the separation of coliforms from salmonellae, but did not appear to be a good technique when trying to separate coliforms from one another when all were able to grow equally well on the solid medium on which the broth was plated. The problem is essentially the same as attempting to isolate salmonellae from faeces using only nutrient broth as a primary medium and subculturing on ordinary nutrient agar. The method of Wilson, Twigg, Wright, Hendry, Cowell \& Maier (1935), in which a subculture is made from the $37^{\circ} \mathrm{C}$. fermented MacConkey broth into (1) $44^{\circ} \mathrm{C}$. MacConkey broth for the Bact. coli type I and (2) citrate at $37^{\circ} \mathrm{C}$. for the citrate-using coliforms, may well be free from criticism on these grounds. Its use, however, was not entirely convenient, and accordingly it was decided to grow the samples of soil in a solid MacConkey's medium thus making an immediate total coliform count. This method had the added advantage of drawing attention easily to the samples most likely to offer interest.

\section{METHODS \\ Primary cultures}

Samples of soil or vegetation were collected in sterile $1 \mathrm{oz}$. screw-capped bottles using a sterile scoop to collect about $10 \mathrm{~g}$. (bottle approximately one-third full). In the laboratory sterile quarter-strength Ringer's solution was added to the level of the neck of the bottle, i.e. approximately twice the weight of soil. The bottles were then well shaken by hand, and as the soil had necessarily been well broken up to get it into the bottle the shaking readily produced a good mixing. After shaking, the suspended particles were allowed to settle for $15 \mathrm{~min}$.

One ml. of the supernatant was added to a tube of MacConkey broth which was incubated at $37^{\circ} \mathrm{C}$. for a time which depended upon the production of gas in the tube, but in any case did not exceed 3 days. One ml. of the supernatant fluid was added to each of two sterile tubes to which MacConkey agar medium (slightly modified, Clegg \& Sherwood, 1947) was added at a temperature of $50^{\circ} \mathrm{C}$. The tubes were 'rolled' under the cold water tap to set the mixture quickly; one tube was incubated at $37^{\circ} \mathrm{C}$. to enumerate the total coliform population and the other was incubated in an accurate water-bath at $44^{\circ} \mathrm{C}$.

Using this technique Clegg \& Sherwood (1947) found in the examination of shellfish that colonies appearing in the roll tube incubated at $44^{\circ} \mathrm{C}$. were almost invariably Bact. coli type I. From 30 samples of soil in this survey a total of 100 colonies grown in the roll tubes at $44^{\circ} \mathrm{C}$. were examined and all were found to be Bact. coli type I. Accordingly, it was presumed throughout the remainder of the survey that well-defined red colonies appearing in the roll tubes incubated overnight at $44^{\circ} \mathrm{C}$. were colonies of Bact. coli type I. 


\section{Isolation of strains}

Colonies in the roll-tube cultures were fished by a sterile wire slightly bent at the end. The number of colonies picked in this way depended upon the counts at the different temperatures. For example, if there were approximately 10 colonies in a roll tube incubated at $37^{\circ} \mathrm{C}$. all were sampled; when there were some 10 colonies in the tube incubated at $44^{\circ} \mathrm{C}$. and approximately 100 in the tube incubated at $37^{\circ} \mathrm{C}$. (a not uncommon type of result) 10-20 of the colonies of the latter tube were samples; samples yielding high counts at $37^{\circ} \mathrm{C}$. and low or nil counts at $44^{\circ} \mathrm{C}$. were specially sought. Consequently on some of the occasions, when only small numbers of colonies (1-10) were grown at $37^{\circ} \mathrm{C}$. they were not picked for further study. On such occasions the coliforms were identified by an examination of the fermented MacConkey broth culture, and the sample was included amongst those shown in the tables as containing 2-10 coliforms per $\mathrm{g}$. Also, when, as sometimes happened, coliforms were grown in the MacConkey broth but not in the roll tube, the count was entered in the tables as being one of 2-10 per g.

Coliforms grown in fermented MacConkey broth were always subcultured and identified except when Bact. coli type I appeared by roll tube culture at $44^{\circ} \mathrm{C}$. to be the overwhelmingly dominant or only coliform present in the sample. In such a case when the presence of Bact. coli type $\mathrm{I}$ in the broth seemed likely a $44^{\circ} \mathrm{C}$. MacConkey test was done for confirmation.

Colonies picked from the roll tubes and subcultures from the MacConkey broths were streaked on MacConkey agar plates and incubated at $37^{\circ} \mathrm{C}$. overnight. It happened not infrequently that pink colonies growing in the roll tube incubated at $37^{\circ} \mathrm{C}$. were found on further examination not to be true coliforms. Only those organisms which grew as red-coloured colonies on the MacConkey agar plates after subculture were considered as possible coliform bacilli. These cultures were tested for purity by plating out isolated colonies on to nutrient agar plates. After overnight incubation single colonies could be picked for differentiation.

\section{Identification of strains}

A well-isolated colony selected from those on the nutrient agar plates was carefully touched on its surface with a sterile platinum wire which was then dipped once into Koser's citrate medium (Oxoid product containing bromo-thymol-blue), taking care not to touch the side of the tube, and thereafter, without recharging, the wire was dipped into peptone water, glucose phosphate broth and MacConkey broth (all made according to Ministry of Health Report No. 71, 1939). Tests for indole production, methyl red reaction, Voges-Proskauer reaction, citrate utilization and fermentation of lactose were carried out in the following manner.

Indole test. The peptone water was incubated overnight at $37^{\circ} \mathrm{C}$. About $1 \mathrm{ml}$. of ether was added to the culture which was vigorously shaken. It was allowed to stand for a few minutes when a few drops of Ehrlich's rosindole reagent were added.

Methyl-red reaction. From the glucose phosphate culture, incubated at $30^{\circ} \mathrm{C}$. 
for 3 days, about $5 \mathrm{ml}$. was withdrawn into a clean test-tube to which were added a few drops of methyl-red solution.

Voges-Proskauer test (Barritt's modification). Two ml. of the same glucose phosphate culture was withdrawn into a test-tube to which $0.6 \mathrm{ml}$. of a $5 \%$ solution of $\alpha$-naphthol and $0.2 \mathrm{ml}$. of a $40 \%$ solution of potassium hydroxide was added. The tube was vigorously shaken and then allowed to stand.

Citrate utilization test. The citrate culture was incubated at $30^{\circ} \mathrm{C}$. for 5 days and examined daily for turbidity and blue coloration.

Fermentation of lactose. The MacConkey broth culture was incubated at $37^{\circ} \mathrm{C}$. for up to 5 days and examined daily for gas production. An organism which produced sufficient gas to fill a third or more of the inverted Durham tube within $48 \mathrm{hr}$. at $37^{\circ} \mathrm{C}$. was considered to be 'typical' in respect of the fermentation of lactose. 'Atypical' strains, even those which produced a mere bubble of gas after 5 days' incubation, were placed with whichever species they had most characters in common.

$44^{\circ} \mathrm{C}$. MacConkey test. In the event of an indole-positive, methyl red-positive, Voges-Proskauer-negative and citrate-negative result being obtained in the previous tests, a subculture was made from the fermented MacConkey broth into a fresh MacConkey broth preheated in the water-bath to $44^{\circ} \mathrm{C}$. This was incubated for 2 days when the production of gas at $44^{\circ} \mathrm{C}$. could be observed. This restricted application of the $\mathbf{4 4}^{\circ} \mathrm{C}$. MacConkey test did not allow for the differentiation of irregular II and irregular VI.

The gelatine liquefaction test was not used in this work. This test differentiates Bact. cloacae from Bact. aerogenes type I and also helps to differentiate irregular III and irregular IV from Bact. coli type II and intermediate type I respectively.

\section{RESULTS}

The samples of soil and vegetation collected from many different sources were roughly grouped as follows:

Group I. Decaying garden vegetation mixed with soil (56 samples).

Group II. Garden soil apparently free from manure (102 samples).

Group III. Woodland soils (40 samples).

Group IV. Soil from ungrazed grassy sites (110 samples).

Group V. Soil from special grassy sites (98 samples). These 98 samples were taken from the protected grassy slopes beside enclosed reservoirs.

The chances of pollution were thought from inspection to vary from group to group being greatest in group I and descending in order to group V.

\section{Group I. 56 samples-decaying garden vegetation}

Nine samples yielded no coliforms either in the roll-tube culture or in the MacConkey broth culture. It was, therefore, concluded that no coliforms were present in $0.5 \mathrm{~g}$. of each of these samples. The three coliform organisms most frequently isolated in the remaining 47 samples were Bact. coli type I, intermediate type $I$ and Bact. aerogenes type $I$. The numbers in which they were found are shown in Table 1. 
Table 1

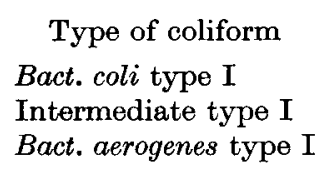

Type of coliform

Bact. coli type I.

Bact. aerogenes type I

\begin{tabular}{|c|c|c|c|}
\hline \multicolumn{4}{|c|}{ No. of samples containing } \\
\hline $2-10 / g$. & $10-100 / \mathrm{g}$ & $100-2000 / \mathrm{g}$. & $>2000 / \mathrm{g}$ \\
\hline 10 & 23 & 7 & 4 \\
\hline 2 & 9 & 0 & 0 \\
\hline 0 & 4 & 0 & 0 \\
\hline
\end{tabular}

Two strains of Bact. coli type II and one of Bact. aerogenes type II were also isolated. They appeared to be present in only small numbers. No intermediate type II or irregular strains were isolated from these 56 samples.

Numbers of coliforms exceeding 2000 per g. were found in only four samples and the coliform isolated on each of these four occasions was Bact. coli type I, the numbers present in both the roll tubes incubated at $37^{\circ} \mathrm{C}$. and at $44^{\circ} \mathrm{C}$. being too numerous to count.

From no sample was a count exceeding 100 per $\mathrm{g}$. of either aerogenes or intermediate strains obtained.

Bact. coli type I was by far the predominating coliform and was isolated from $44(78.5 \%)$ of the 56 samples. In fact from only 3 samples was a coliform isolated in the absence of Bact. coli type I. Two of these were samples which contained intermediate type $I$ in numbers of less than 10 per $g$. The third sample was found to contain 100 coliforms per g. Apparently equally represented in this number were Bact. aerogenes type I, Bact. aerogenes type II and intermediate type I.

Intermediate type I was isolated from only $11(19 \cdot 6 \%)$ and Bact. aerogenes type I from only $4(7 \cdot 1 \%)$ of the 56 samples.

\section{Group II. 102 samples-garden soils}

Seventy-three of the 102 samples were found to contain coliform bacilli. No coliforms were isolated from $0.5 \mathrm{~g}$. amounts in the remaining 29 samples. The coliform types that were found and the numbers in which they occurred are shown in Table 2.

Table 2

\begin{tabular}{|c|c|c|c|c|}
\hline \multirow[b]{2}{*}{ Type of coliform } & \multicolumn{4}{|c|}{ No. of samples containing } \\
\hline & $2-10 / g$. & $10-100 / \mathrm{g}$ & $100-2000 / \mathrm{g}$ & $>2000 / \mathrm{g}$ \\
\hline Bact. coli type I & 28 & 18 & 2 & 2 \\
\hline Intermediate type I & 11 & 15 & 1 & 1 \\
\hline Bact. aerogenes type I & 4 & 3 & 1 & 0 \\
\hline
\end{tabular}

Only three samples were found to contain more than 2000 coliforms per g. In two of these cases the coliform isolated was Bact. coli type I, the number of colonies in both roll tubes being too numerous to count. From the third sample the red-coloured colonies grown in the roll tube incubated at $37^{\circ} \mathrm{C}$. were too numerous to count whilst none developed in the roll tube incubated at $\mathbf{4 4}^{\circ} \mathrm{C}$. Thirty of these colonies were picked and plated; five failed to grow on the MacConkey agar plate; three grew as colourless non-coliform colonies and the 
remaining 22 were identified as intermediate type I. Of these, however, only three showed 'typical' gas production in MacConkey broth at $37^{\circ} \mathrm{C}$.; the others produced little more than a bubble of gas in 5 days. It thus appeared that this sample contained some thousands of intermediate type I coliforms per gram, but that the majority of them were micro-aerogenic forms. Surprisingly, the only coliform obtained from the sample by MacConkey broth culture was Bact. coli type I. It was supposed that this organism was present in the sample in only very small numbers, but that nevertheless it had overgrown the intermediate strains.

One further specimen of this group deserves special mention. This gave a count of 2000 Bact. aerogenes type I strains per gram of soil (20 colonies were picked for identification and this was the highest count of an aerogenes strain found in soil). Fifteen of the twenty strains isolated were found to produce only slight amounts of gas in MacConkey broth at $37^{\circ} \mathrm{C}$. even after prolonged incubation; the remaining five showed 'typical' acid and gas production at $37^{\circ} \mathrm{C}$, as did the aerogenes type I isolated by broth culture.

As shown in the table Bact. coli type I was the predominating coliform isolated, occurring altogether in $50(49 \%)$ of the 102 samples. Intermediate type I was found in $28(27 \cdot 4 \%)$ and Bact. aerogenes type $\mathrm{I}$ in $8(7.8 \%)$ of the samples.

\section{Group III. 40 samples-woodland soils}

Twenty-nine of the 40 samples yielded coliforms from $0.5 \mathrm{~g}$. amounts. As shown in Table 3 the numbers found were not large.

Table 3

Type of coliform
Bact. coli type I
Intermediate type I
Bact. aerogenes type I

\begin{tabular}{|c|c|c|c|}
\hline \multicolumn{4}{|c|}{ No. of samples containing } \\
\hline $2-10 / \mathrm{g}$ & $10-100 / \mathrm{g}$ & $100-2000 / \mathrm{g}$ & $>2000 / \mathrm{g}$. \\
\hline 16 & 6 & 0 & 0 \\
\hline 2 & 6 & 1 & 0 \\
\hline 4 & 7 & 0 & 0 \\
\hline
\end{tabular}

A strain of intermediate type II was also isolated from one of these samples.

Only one count exceeded 100 per $\mathrm{g}$. The coliform isolated on this occasion was identified as an intermediate type I which fermented lactose feebly.

As can be seen in Table 3 the predominating coliform was again Bact. coli type I, found in $22(55.0 \%)$ of the 40 samples. Intermediate type I was found in $9(22.5 \%)$ and Bact. aerogenes type $I$ in $11(27.5 \%)$ of the samples. This was the highest percentage occurrence of aerogenes strains in the five groups.

\section{Group IV. 110 samples-grassland soils}

Coliforms were isolated from $0.5 \mathrm{~g}$. amounts of 97 of these samples. Table 4 shows the types found and the numbers in which they occurred in the samples.

Bact. coli type II also was isolated by MacConkey broth culture from two of the samples.

Only three samples were found to contain more than 2000 coliforms per g., and one of these contained only Bact. coli type I. The other two samples yielded inter- 
mediate type I in numbers too high to count. Not only did the vast majority of these appear to be micro-aerogenic forms but they were also somewhat atypical in that growth in Koser's citrate at $30^{\circ} \mathrm{C}$. proceeded slowly; after 3 days only a faint flocculent turbidity was shown, and not until after 5 days' incubation was full turbidity and colour change apparent.

Table 4

Type of coliform
Bact. coli type I
Intermediate type I
Intermediate type II
Bact. aerogenes type I

\begin{tabular}{cccc}
\multicolumn{4}{c}{ No. of samples containing } \\
$2-10 / g$. & $10-100 / g$. & $100-2000 / g$. & $>2000 / g$ \\
12 & 5 & 2 & 1 \\
40 & 17 & 15 & 2 \\
7 & 2 & 0 & 0 \\
5 & 6 & 3 & 0
\end{tabular}

The MacConkey broth culture of one of these two samples yielded in addition to a 'typical lactose-fermenting' intermediate type I a strain of Bact. coli type II. It was possible that this strain was represented in the dense colony growth in the roll tube incubated at $37^{\circ} \mathrm{C}$. but sampling (20 pickings were made) failed to detect it. The MacConkey broth culture of the other sample yielded only an intermediate type I strain.

Intermediate type I was by far the predominating coliform and was isolated from $74(67.2 \%$ ) of the 110 samples. Bact. coli type I was isolated from only 20 $(18.1 \%)$ of the samples. As shown in Table 4 intermediate type II was also found in small numbers in $9(8.1 \%)$ whilst Bact. aerogenes type I was isolated from $14(12 \cdot 7 \%)$.

\section{Group V. 98 samples-protected grassland soils}

As in group IV these samples were chosen from grassy banks and the results obtained were very similar. Coliforms were isolated from $0.5 \mathrm{~g}$. amounts in 75 of these 98 samples. The numbers in which they were found are shown in Table 5.

Table 5

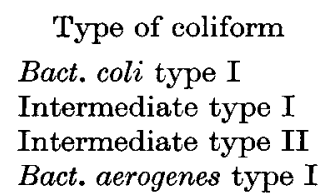

\begin{tabular}{|c|c|c|c|}
\hline \multicolumn{4}{|c|}{ No. of samples containing } \\
\hline $2-10 / \mathrm{g}$. & $10-100 / g$ & $100-2000 / \mathrm{g}$ & $>2000 / g$. \\
\hline 8 & 2 & 0 & 0 \\
\hline 36 & 13 & 11 & 0 \\
\hline 6 & 2 & 0 & 0 \\
\hline 3 & 4 & 1 & 0 \\
\hline
\end{tabular}

No counts of more than 2000 coliforms per g. were recorded. Eleven of the samples yielded more than 100 per $\mathrm{g}$. of intermediate type I, and one sample yielded more than 100 Bact. aerogenes type I. In this latter case all the aerogenes present appeared to ferment lactose feebly.

As in group IV, intermediate type I was by far the predominant coliform being isolated from $60(61.2 \%)$ of the 98 samples. Bact. coli type I was found in only 
$10(10 \cdot 2 \%)$ of the samples. Intermediate type II and Bact. aerogenes type II were isolated on 8 occasions $(8 \cdot 1 \%)$.

Whilst these examinations failed to demonstrate the regular isolation of aerogenes or intermediate coliforms in large numbers from soil and vegetation, an unexpectedly high number of samples was found to contain one or more coliforms. It is possible that the successful isolation of some of these coliforms merely illustrates their ubiquity and the widespread nature of faecal pollution. However, a comparison of the results in the different groups indicates that the intermediate types at least were apparently unassociated with faecal pollution.

In the table that follows (Table 6) the proportion of samples within each group yielding coliforms of different varieties is expressed as a percentage. The number of times no coliforms were obtained is similarly expressed. Bact. aerogenes type $\mathbf{I}$ and Bact. aerogenes type II are considered together as are intermediate type I and intermediate type II.

\section{Table 6}

\begin{tabular}{|c|c|c|c|c|c|c|c|c|c|}
\hline & & & & No. & sam & cont & ining & & \\
\hline & & $\mathrm{col}$ & rims & & $\begin{array}{l}c o l i \\
\text { e I }\end{array}$ & $\begin{array}{l}\text { In } \\
\text { me }\end{array}$ & $\begin{array}{l}\text { r- } \\
\text { ates }\end{array}$ & & $\begin{array}{l}\text { ct. } \\
\text { enes }\end{array}$ \\
\hline & of samples & No. & $\%$ & No. & $\%$ & No. & $\%$ & No. & $\%$ \\
\hline Group I & 56 & 9 & $16 \cdot 0$ & 44 & $78 \cdot 5$ & 11 & $19 \cdot 6$ & 4 & $7 \cdot 1$ \\
\hline Group II & 102 & 29 & $28 \cdot 4$ & 50 & $49 \cdot 0$ & 28 & $27 \cdot 4$ & 8 & $7 \cdot 8$ \\
\hline Group III & 40 & 11 & $27 \cdot 5$ & 22 & $55 \cdot 0$ & 10 & $25 \cdot 0$ & 11 & $27 \cdot 5$ \\
\hline Group IV & 110 & 13 & $11 \cdot 8$ & 20 & $18 \cdot 1$ & 79 & $71 \cdot 8$ & 14 & $12 \cdot 7$ \\
\hline Group V & 98 & 23 & $23 \cdot 4$ & 10 & $10 \cdot 2$ & 63 & $64 \cdot 2$ & 8 & $8 \cdot 1$ \\
\hline
\end{tabular}

From a topographical consideration of the sites from which the samples were chosen it was expected that the number of polluted samples would be greatest in group I, then group II, then III, then IV, and then V. The order of incidence of samples containing Bact. coli type I within the groups was found, as is shown in the table, to be as follows: most in group I, then III, then II, then IV, and then V. This agrees closely with the expected order of pollution above and is thus in favour of Bact. coli type I being the chosen index of pollution.

On the other hand, if all the various types of coliforms were derived from the intestine and if all coliforms were of equal sanitary significance, the occurrence of negative samples should be most numerous in those groups taken from sites least exposed to pollution, i.e. in descending order groups V, IV, III, II and I. The actual descending order of incidence of negative samples was groups II, III, V, I and IV. There is no agreement here, and it would seem that the various types of coliforms do not equally indicate faecal pollution. It is possible that intermediates survive longer in soil and thus some of the results might be explained; mere survival, however, offers no explanation of the fact that a greater proportion of the less polluted soils yielded intermediates. It is possible, on the other hand, that these intermediates were established in soil, but if so, one might have thought that on occasion they would have been found in exceedingly large numbers. 


\section{FURTHER STUDIES OF SAMPLES OF SOIL FROM SELECTED GRASSY SITES}

Samples of soil from the grassy slopes surrounding a protected reservoir in the Cardiff City boundary had shown very little evidence of faecal pollution as judged by the presence of Bact. coli type I. On the other hand, a very high proportion of the samples from these sites had yielded intermediate type I strains. It was thought desirable to make further tests for evidence of faecal pollution. It was thought that if other tests confirmed the absence of such pollution the probability that the intermediate type I did not indicate faecal pollution, would be increased. Accordingly, 33 more samples were collected, and in addition to the tests already described, special tests were made for Clostridium welchii and Streptococcus faecalis.

Media

\section{Methods}

In addition to the media used and described previously in the examination of 406 samples of soil and vegetation the following were used. Double-strength MacConkey broth in $10 \mathrm{ml}$. amounts was used to examine larger amounts of soil for coliforms. Wilson-Blair medium was used for the isolation of $\mathrm{Cl}$. welchii. Both of these were made according to the Ministry of Health Report No. 71, 1939. Azide medium used in the isolation of Strep. faecalis was made according to Childs \& Allen (1953).

\section{Primary cultures}

Samples of soil in approximately $50 \mathrm{~g}$. amounts were collected in large sterile bottles which had been weighed. By weighing the bottle with its sample the weight of soil was known. Twice the weight of sterile saline was added and the bottle vigorously shaken. After shaking, the suspended particles were allowed to settle for $15 \mathrm{~min}$.

\section{Isolation of coliforms}

As before, $1 \mathrm{ml}$. of the supernatant was added to each of two roll tubes and to $5 \mathrm{ml}$. of MacConkey broth (single strength). In addition $10 \mathrm{ml}$. were added to $10 \mathrm{ml}$. MacConkey broth (double strength).

One roll tube was incubated at $37^{\circ} \mathrm{C}$. the other at $44^{\circ} \mathrm{C}$., whilst both MacConkey broth cultures were incubated at $37^{\circ} \mathrm{C}$. Isolation and identification of strains was made as before.

\section{Enumerations}

Once again it was assumed that all the bacteria were released from the soil into the liquor. Therefore, the number of coliforms contained in $1 \mathrm{~g}$. of soil was obtained by multiplying the count at $37^{\circ} \mathrm{C}$. by two. In all, $12 \mathrm{ml}$. of supernatant were cultured at $37^{\circ} \mathrm{C}$. for coliforms and this was equivalent to $6 \mathrm{~g}$. of soil. The numerical description 2-10 per g. again included isolation by MacConkey broth culture only. 


\section{Isolation of Clostridium welchii}

Five ml. of the supernatant, equivalent to $2 \frac{1}{2} \mathrm{~g}$. of soil, was heated to $80^{\circ} \mathrm{C}$. for $10 \mathrm{~min}$. and added to $15 \mathrm{ml}$. of Wilson-Blair agar medium which had been melted and allowed to cool to $50^{\circ} \mathrm{C}$. A plate was poured and incubated anaerobically at $37^{\circ} \mathrm{C}$. When $\mathrm{Cl}$. welchii was present the large black colonies were easily recognized and a colony was picked and tested by the Nagler reaction (Mackie \& McCartney, 1953).

Isolation of Streptococcus faecalis (resuscitation method of Childs \& Allen, 1953)

Ten ml. of the supernatant fluid, equivalent to $5 \mathrm{~g}$. of soil, were added to a tube containing $5 \mathrm{ml}$. of quadruple strength nutrient broth and incubated at $37^{\circ} \mathrm{C}$. for $2 \mathrm{hr}$. After this period of resuscitation $5 \mathrm{ml}$. of quadruple strength azide solution was added and the tube incubated in a water-bath at $45^{\circ} \mathrm{C}$. Tubes showing growth were subcultured on MacConkey agar and the presence of Strep. faecalis confirmed by morphological appearances.

\section{Results}

The amount of soil sampled was greater in this series than in the series recorded under group $V$, and it was expected that a smaller proportion would be free from coliforms and Bact. coli type I in particular.

\section{Occurrence of coliforms}

Only one sample failed to yield coliforms. The numbers of coliforms obtained from the remaining thirty-two samples are shown in Table 7.

\section{Table 7}

Type of coliform
Bact. coli type I
Intermediate type I
Intermediate type II
Bact. aerogenes type I

\begin{tabular}{|c|c|c|c|}
\hline \multicolumn{4}{|c|}{ No. of samples containing } \\
\hline $2-10 / g$. & $10-100 / \mathrm{g}$. & $100-2000 / \mathrm{g}$. & $>2000 / g$ \\
\hline 6 & 1 & 3 & 0 \\
\hline 13 & 4 & 4 & 1 \\
\hline 9 & 0 & 1 & 0 \\
\hline 4 & 1 & 2 & 0 \\
\hline
\end{tabular}

It can be seen that only one count above 2000 per g. was recorded. This was from a sample which yielded 3000 intermediate type I strains, the majority of which appeared to be atypical in respect of lactose fermentation. Of 20 colonies picked 18 produced only a bubble of gas in MacConkey broth after 5 days' incubation at $37^{\circ} \mathrm{C}$. The remaining two showed typical gas production within 2 days, as did the intermediate type I strain isolated by MacConkey broth culture.

Two samples which yielded more than one hundred Bact. aerogenes type I per g. are worthy of special mention. From one of these a count of 780 coliforms per g. was obtained. Twenty of the colonies were picked and 3 were identified as intermediate type $\mathrm{I}$ and 17 as Bact. aerogenes type I, i.e. by proportion about 700 of the total number per gram were aerogenes. Every one of the 17 aerogenes colonies picked was atypical in respect of lactose fermentation and only inter- 
mediate type I was isolated by MacConkey broth culture. In the other sample a count of 600 Bact. aerogenes type I, all apparently slow fermenters, was obtained. Surprisingly, however, the MacConkey broth culture of this sample yielded an intermediate type I and an intermediate type II strain but no aerogenes strains. It is possible that these intermediate strains, though numerically inferior, outgrew the aerogenes strains in the broth culture.

\section{Frequency of isolation of strains}

Bact. coli type I was isolated from 10 specimens, i.e. from $30 \%$ as compared with $10 \%$ when the smaller sample was cultured in the first series recorded under group V.

Intermediate type I strains were isolated from 22 , i.e. $66 \%$ as compared with $61 \%$ when the smaller sample was cultured.

Thus, increasing the amount of soil examined increased the proportion yielding Bact. coli type I three times, but the proportion yielding intermediate type I remained constant. This in itself indicates that the intermediate type I strains were more numerous in the soil. A study of Table 7 shows this to be true but not markedly so.

Ten samples were found to contain intermediate type II, i.e. from $30 \%$ of the samples as compared with $8 \%$ of the samples when a smaller amount of soil was cultured.

Bact. aerogenes type I was isolated from 7 samples, i.e. from approximately $21 \%$ as compared with $8 \%$ when a smaller sample was cultured. Only one of these contained Bact. coli type I.

Of the 22 samples yielding intermediate type I only 4 yielded Bact. coli type I; of the 11 samples not yielding intermediate type I, 6 yielded Bact. coli type I. There appeared, therefore, to be no association between the occurrence of these two coliforms in soil. The absence of association might be thought to be more apparent than real as there would appear to be many problems in the identification of several species in mixed culture when no reliable selective culture medium is available to help the separation. This problem is being further studied.

\section{Occurrence of Clostridium welchii}

$C l$. welchii has been found in soil, water, milk, dust, sewage and the intestinal canal of man and animals (Topley \& Wilson, 1946). Thresh et al. (E. Windle Taylor, 1949) comment that, though a few strains of the spore-bearing anaerobes may have their natural habitat in soil and decaying animal and vegetable matter, they are for the most part essentially associated with the intestine of man and animals. In the Ministry of Health pamphlet on the Bacteriological Examination of Water Supplies (Report No. 71, 1939) the presence of $\mathrm{Cl}$. welchii in water is taken as an indication of the occurrence of faecal pollution.

Twenty-nine of the thirty-three samples of soil contained $\mathrm{Cl}$. welchii. None of the four negatives yielded Bact. coli type I, but three of them yielded other coliforms in small numbers. 
Assuming that $\mathrm{Cl}$. welchii is in fact indicative of faecal pollution this result would seem to be further evidence of the virtual impossibility of obtaining a soil entirely free from animal pollution.

\section{Occurrence of Streptococcus faecalis}

Strep. faecalis occurs principally in the faeces of man and animals, which may contain up to many millions per gram. According to Thresh et al. (E. Windle Taylor, 1949) they are absent from virgin soil and unpolluted water. Houston (1910) found that streptococci died out rapidly in water, and Savage \& Wood (1918) indicated that when human faeces, animal excreta or domestic sewage was added to water the streptococci died out rather more quickly than Bact. coli. On the other hand, Horrocks (1901) found streptococci to persist in sewage after the disappearance of Bact. coli. It would seem likely, therefore, that any source yielding Strep. faecalis has at some time or other been associated with manurial pollution.

Strep. faecalis was isolated from 8 of the 33 samples, and from 6 of these Bact. coli type I was also isolated. Strep. faecalis was not isolated from a sample which did not also contain $\mathrm{Cl}$. welchii.

These further tests for $C l$. welchii and Strep. faecalis failed to confirm the absence of faecal pollution. Of the 33 samples there were only 4 from which neither of these indicators of pollution was obtained. One of these 4 samples contained no coliforms in the amounts tested, 2 yielded intermediate type $I$ by MacConkey broth culture only (i.e. in very small numbers) and 1 yielded 40 coliforms per g. (28 Bact. aerogenes and 12 intermediate type $\mathrm{I}$ ).

It was not found possible to make any striking comparisons between the association of Bact. coli type I with the other indicators of pollution, Cl. welchii and Strep. faecalis. The occurrence of $\mathrm{Cl}$. welchii and Strep. faecalis in these samples would appear to indicate contamination at some time more or less remote.

\section{SUMMARY}

Coliforms were readily obtained from many soils. In samples taken from sites exposed to animal contamination Bact. coli type I occurred predominantly. A large number of samples taken from grassy banks, only remotely exposed to contamination, were found to contain intermediates. It was found that the greater the probable degree of contamination of the soil the higher was the proportion of Bact. coli type I, and that the less the probable degree of contamination the higher was the proportion of intermediates. It is difficult to explain this merely on the basis of the prolonged survival of intermediates in soil, and it would appear obvious that the source of these intermediates lay elsewhere than in animal faeces. The numbers in which they were found in soil, however, were not of the order expected of bacteria living in their natural environment, and consequently it was equally difficult to conclude that these intermediates were actively established in soil.

This survey was made when the author held a Medical Research Council Scholarship, and the author wishes to record his gratitude to the Council for their support. I wish to thank Prof. Scott Thomson for his guidance. 


\section{REFERENCES}

Bardsley, D. A. (1948). J. Hyg., Camb., 46, 267.

Childs, E. \& Allen, L. A. (1953). J. Hyg., Camb., 51, 468.

ClegG, L. F. L. \& Sherwood, H. P. (1947). J. Hyg., Camb., 45, 504.

Griffin, A. M. \& StuART, C. A. (1940). J. Bact. 40, 83.

Horrocks, W. H. (1901). Bacteriological Examination of Water. Cited by Thresh, Beale \& Suckling (1949).

Houston, A. C. (1910). 5th Res. Rep. Metropolitan Water Board. Cited by Thresh, Beale \& Suckling (1949).

Mackie, T. J. \& MoCartney, J. E. (1953). Handbook of Practical Bacteriology, 9th ed. Edinburgh and London: Livingstone.

Ministry of Health (1939). Rep. publ. Hlth med. Subj., Lond., no. 71.

PARr, L. W. (1939). Bact. Rev. 3, 1.

Savage, W. G. \& Wood, T. (1918). J. Hyg., Camb., 16, 227.

TAYLOR, C. B. (1942). J. Hyg., Camb., 42, 23.

TAYLOR, C. B. (1951). J. Hyg., Camb., 49, 162.

Thomas, S. B., Jones, G. E. \& Frankin, P. M. (1951). Proc. Soc. appl. Bact. 14, 45.

Thomas, S. B. \& MoQUillin, J. (1952). Proc. Soc. appl. Bact. 15, 41.

Thresh, J. C., Beale, J. F. \& Suckling, E. V. (1949). The Examination of Waters and Water Supplies, 6th ed. By E. Windle Taylor. London: Churchill.

Topley, W. W. C. \& Wilson, G. S. (1946). The Principles of Bacteriology and Immunity, 3rd ed. By Wilson, G. S. \& Miles, A. A. London: Arnold.

Wirson, G. S., Twigg, R. S., Wright, R. C., Hendry, C. B., Cowell, M. P. \& Maier, I. (1935). Spec. Rep. Ser. med. Res. Coun., Lond., no. 206.

(MS. received for publication 6. 1. 56) 